\title{
Flipped-Learning Approach in Business English Translation Course in a Chinese Independent College
}

\author{
Zheying Xiao ${ }^{1}$ \\ ${ }^{1}$ School of Foreign Studies, Yangtze University College of Arts and Science, Jingzhou, China \\ Correspondence: Zheying Xiao, School of Foreign Studies, Yangtze University College of Arts and Science, 27 \\ Yingdu Road, Jingzhou District, Jingzhou City, Hubei Province, China.
}

Received: January 7, 2022

Accepted: January 21, 2022

Online Published: January 28, 2022

doi: 10.5539/elt.v15n2p61

URL: https://doi.org/10.5539/elt.v15n2p61

\begin{abstract}
This study applies and tests the efficacy of the flipped learning approach designed for a business English translation course in a class consisting of 26 third-year business English major students in an independent college, the Yangtze University College of Arts and Science. Because the students in independent colleges usually have weak English skills and lack learning awareness, this study explores a way to improve their competence in business translation while changing the traditional lecture-centred methodology. After finishing the 16-week semester of application, a posttest would be conducted to be compared to a pretest that was administered at the beginning of the course to test the efficacy of the new flipped learning approach. From the data collected, this paper suggests the flipped learning approach can stimulate students' self-learning before class, enhance their engagement in class and significantly improve their translation competence. Therefore, this study proposes using a flipped learning approach in business English translation courses taught in Chinese independent colleges.
\end{abstract}

Keywords: business English, translation course, flipped learning, Chinese independent college, educational design

\section{Introduction}

Since the proposal of The Belt and Road strategy, China has had increasingly close cooperation and more frequent exchanges with countries where business English translation is gaining popularity and significance, which has led to a rapidly growing demand for business English translators. Quite a few colleges in China, public or private, have offered business English courses, including the Yangtze University College of Arts and Science, where the author of this paper works, as part of its provincial first-class undergraduate major. It is currently an independent college but is the process of transformation.

In a flipped learning process, teachers withdraw from the centre of a traditional classroom setting to create a student-oriented classroom where students become the centre of the learning process while receiving proper guidance and assistance from teachers. In other words, in contrast with a traditional lecture-based teaching model, a flipped learning approach concentrates on the learning process by providing students with the autonomy to control their self-learning room and individualized self-learning methods.

Nevertheless, the flipped learning approach has not been sufficiently researched in terms of its application and efficacy in independent Chinese colleges. The past decade has witnessed the profound and creative implementation of and research about using a flipped learning approach in a range of disciplines and courses in Chinese universities. Business English translation courses in Chinese universities have had a limited application, and there is not sufficient research on the flipped learning model or its use in Chinese independent colleges. Based on the previous literature and the experimental application of this study at the authors' college, this study explores the feasibility and efficacy of the flipped learning approach for teaching business English translation courses in Chinese independent colleges.

\section{Literature Review}

Flipped learning or the flipped classroom have recently become one of the most heatedly discussed and used teaching approaches around the world. Educause (2012) has posited a widely accepted definition of the flipped classroom as "a pedagogical model in which the typical lecture and homework elements of a course are 
reversed" (p. 1). However, the Flipped Learning Network (2015) has defined flipped learning as a pedagogical approach in which direct instruction moves from the group learning space to the individual learning space, and the resulting group space is transformed into a dynamic, interactive learning environment where the educator guides students as they apply concepts and engage creatively in the subject matter.

Scholars have not found evidence about the first time of employing flipped learning or flipped classroom. For instance, "peer instruction" prevailing in the 1990s has much in common with flipped learning. However, one commonly accepted fact is that Jon Bergman and Aaron Sams (Bergmann \& Sams, 2012) proposed the the concept of flipped learning approach after successfully practicing it in their chemistry course to alter conventional teaching methods. Subsequently, research on flipped learning has rapidly developed. On December 28, 2021, I searched CNKI, China's academic publications database, with "flipped-learning approach" as key words or theme words and found the number of relevant publications, including journals, theses and dissertations and books during the period from 2012 to 2021 was more than 27,000. However, in stark contrast to the many research publications about using the flipped learning approach in other courses, few research articles focused on using it for a business English translation course. Specifically, there were none before 2016, but number slowly increased to fewer than 40 by the end of 2021. Among these publications, empirical studies and theoretical reflections comprise the two main categories. For instance, one was a project-based flipped learning model for a business English translation course (Deng, 2018); another study tested the effectiveness of the flipped classroom and examined the influencing factors $(\mathrm{He} \& \mathrm{Li}, 2020)$. Other research papers included the following: "The Teaching Design for the Business English Translation Flipped Classroom in the Era of Mass Data" (Li, 2021); "An Exploration into the Teaching Plan of Flipped Learning in a Russian Translation Course" (Ji, 2021); "The Empirical Study of Applying a Flipped Classroom to Business Interpretation in a Chinese Polytechnic College" (Xu, 2016); "The Empirical Research on the Teaching Model of a 'Flipped Classroom' in College Business English Translation Course" (Wang \& Huang, 2016); "Strategies of Business English Translation from the Perspective of Functional Equivalence" (Hui, 2018). However, there were no publications about using the flipped learning approach in a business English translation course at a Chinese independent college. There is no doubt the existing studies have cast light on the concept and significance of the flipped learning in China. However, more research about flipped learning in the context of Chinese independent colleges needs to be conducted.

\section{Main Purpose and Questions}

Based on the business English translation course at the Yangtze University College of Arts and Science, this study employed the flipped learning approach and tested its efficacy. At this college, this course has long employed the traditional teacher-centred approach, which can make students feel bored and become absentminded during class. Because it is an independent college, students admitted to this college usually have a weak grounding in English and lack the self-learning awareness. The main purpose of this research is to propose and test the flipped learning approach in line with the features of students enrolled in this kind of college and the nature of translation. The following is a brief introduction to the course for business English translation in this college along with this study's research questions.

\subsection{Course Introduction}

The two-credit course for business English translation at Yangtze University College of Arts and Science is usually arranged for students to take in the first term of the third year of the business English major program and spans 16 teaching weeks. The detailed arrangement for the course is shown in Table 1.

Table 1. Course Arrangement

\begin{tabular}{llll}
\hline Week 1 & Week 2-7 & Week 8-15 & Week 16 \\
\hline Course orientation & $\begin{array}{l}\text { English-Chinese } \\
\text { comparison and contrast }\end{array}$ & $\begin{array}{l}\text { Translation of different } \\
\text { business texts }\end{array}$ & Posttest
\end{tabular}

Fundamental translation

Pretest theories and translation skills

The course orientation and pretest are arranged in the first session and the second one, respectively, during the first week. The period from week 2 to 7 covers two main aspects: the first is a comparison and contrast in terms of words, sentences and texts between English and Chinese to lay the foundation for students to better understand the similarities and differences between the two languages for translation learning; the second part covers basic translation theories and skills, including amplification, inversion, conversion, omission, extension 
and repetition. Then, students are trained to translate specific business texts, such as company profiles, business cards, manuals, advertisements, trademarks, business letters, business contracts, letters of credit and exhibitions. In the final week (Week 16), a posttest is given to the students before they can review for the final exam.

\subsection{Questions to Be Addressed}

The two questions that will be considered in this paper are as follows:

1) How can instructors effectively employ a flipped learning approach in a business English translation course taught in a Chinese independent college by considering the features of students at this college and the nature of translation?

2) Has the competence of this college's business English translation students been improved after using the flipped learning approach?

\subsection{Factors to Be Considered: Characteristics of Applicants and the Nature of Translation}

This study considered the characteristics of students in Chinese independent colleges and the nature of translation when testing the efficacy of the flipped learning approach. This study proposed a flipped learning approach that should be in line with the above-mentioned considerations.

\subsection{Characteristics of Applicants}

By conducting a survey on English major students in Chinese independent colleges, I found their ability to study on their own is generally low, which is primarily reflected in the following four aspects: lack of planning, lack of self-positioning, inability to learn and apply English through multiple channels and lack of effective independent learning guidance. Twenty-six business English majors in their junior year at Yangtze University College of Arts and Science participated in this research. They are all used to a passive learning model (i.e., the traditional lecture-oriented methodology), involving taking notes in class from teachers' lectures and finishing class assignments. Few students will preview or review class content if teachers do not ask them to in advance or be active in class. They become absentminded because classes do not make them completely engaged and involved in studying.

\subsection{The Nature of Translation}

Subjectivity is an aspect of translation that calls for translators to be involved the entire translation process, including early-stage preparation, translation and polishing in later stages. The nature of translation, therefore, requires teachers to attach more importance to the process of translation instead of exam results, which are prioritized in a traditional lecture-centred method of teaching. However, in the context of the flipped learning approach, students are placed at the centre of learning and in their own space.

\section{Methods}

This study employs the flipped learning approach and examines its efficacy by comparing the results of a pretest and posttest. The entire process of applying the flipped learning approach requires the full engagement of the teacher and students in all pre-class activities as well as during class and after it. Table 2 shows the specific arrangement of how the flipped learning approach was used in each class in this course.

Table 2. Flipped Learning Approach of Each Class

\begin{tabular}{|c|c|c|c|c|}
\hline \multicolumn{5}{|l|}{ Each Class } \\
\hline $\begin{array}{l}\text { Before } \\
\text { class }\end{array}$ & $\begin{array}{l}\text { 1. Watch MOOC } \\
\text { (massive open online } \\
\text { courses) videos }\end{array}$ & $\begin{array}{l}\text { 2. Finish the tasks given by } \\
\text { the teacher that are related to } \\
\text { the MOOC videos }\end{array}$ & $\begin{array}{l}\text { 3. Prepare the } \\
\text { questions for the } \\
\text { class }\end{array}$ & \\
\hline $\begin{array}{l}\text { First } \\
\text { session }\end{array}$ & $\begin{array}{l}\text { 1. Present the finished } \\
\text { tasks in class }\end{array}$ & 2. Feedback from the teacher & $\begin{array}{l}\text { 3. Present the } \\
\text { questions for the } \\
\text { class to discuss }\end{array}$ & $\begin{array}{l}\text { 4. Answers from the } \\
\text { students and teacher }\end{array}$ \\
\hline $\begin{array}{l}\text { Second } \\
\text { session }\end{array}$ & $\begin{array}{l}\text { 1. In class translation } \\
\text { task }\end{array}$ & $\begin{array}{l}\text { 2. Discussion in groups about } \\
\text { the employed translation skills } \\
\text { and difficulties in the } \\
\text { translation task }\end{array}$ & 3. Group assessment & $\begin{array}{l}\text { 4. Feedback and } \\
\text { conclusion from the } \\
\text { teacher }\end{array}$ \\
\hline Post-class & \multicolumn{4}{|c|}{$\begin{array}{l}\text { 1. Finish the exercises in the unit } \\
\text { 2. Finish the journal for this class, including the reflection }\end{array}$} \\
\hline
\end{tabular}




\subsection{Before Class}

To begin, the teacher searched for the appropriate sessions from China's massive open online courses (MOOC) for students to watch, including the following: 1) business English translation from Shanghai International Studies University, 2) business English-Chinese and Chinese-English translation from the East China University of Political Science and Law, and 3) a textbook on English-Chinese translation from Jiangxi University of Finance and Economy. After watching the videos, the students were asked to finish tasks or quizzes to ensure they had watched the videos attentively and did not miss any important information. The students then prepared questions they found confusing to be addressed in class.

\subsection{The First Session (45 Mins)}

Students presented their finished tasks in the beginning of the first session. The tasks before class were always related to the video they had watched before and relevant to the class topic. The tasks included a range of activities, from presenting key points in slides to answering the questions. Then, the teacher gave feedback on these performances. Later, it was the students' turn to ask their questions for the entire class to think about and discuss before the teacher gave their final feedback. The first session was intended to help students acquire a thorough understanding of the unit's content.

\subsection{The Second Session (45 Mins)}

The teacher presented the source text they had selected for the students to translate to the target language while providing clear requirements and criteria for the translating. The translation exercises held during week 2 and week 7 were intended to provide students with translation skills by emphasizing various skills such as inversion, conversion, amplification, omission and extension. The translation projects during the following 8 weeks were to train students to translate different business texts such as business cards, business correspondence, letters of credit, advertisement and manuals. The 26 students were divided into four groups. Each group started by discussing the text and criteria for the translation before dividing up the work among the members. During the translation process, the students could receive help from their electronic dictionaries, peers and teachers, who walked through the classroom to observe and help. When everyone finished their part, all the group members combined their individual parts into a first translation draft. Then, they discussed the problems of the translated work and tried to revise it to create the second and final translation versions. During their discussions, one student was chosen to record their discussion about problems and skills employed, among other issues. When all four groups finished, they were required to exchange their translated work with other groups and evaluate their translated texts based on the criteria. Thereafter, each group selected one member to compare its translation version with the other group's work in terms of choice of skills, good points and bad points to help the students better observe and assess the other's performance and learn from each other. All the students then chose the best version of translation. Finally, the teacher, as the guide and observer during the process, provided final comments on each group's performance, in terms of teamwork, translation results and group assessments, and proposed some suggestions for students' future translation work.

\subsection{Post-Class}

The students had two tasks to complete after each class:

1) Keep a translation diary in which they wrote down what they acquired and achieved during the flipped learning teaching; and

2) Finish the exercises in the textbook unit.

\subsection{Tests Before and After the Application}

Students took the pretest during the second session (45mins) of the first class and the posttest in the first session (45mins) of the final class; both tests had similar difficulty levels. Specifically, each test comprised one passage of about 200 words to be translated to English from Chinese and one passage of roughly 200 words to be translated to Chinese from English within 45 minutes. The following table represents the grading standards for the two tests. 
Table 3. Grading Standards for the Tests

\begin{tabular}{lll}
\hline Criteria & Sub-criteria & Grade \\
\hline Faithfulness & Faithful to the source content & 40 \\
& $\begin{array}{l}\text { Faithful to the genre of the source text } \\
\text { Faithful to the appeal of the author } \\
\text { Smoothness }\end{array}$ & $\begin{array}{l}\text { Conjunctions } \\
\text { Coherence and cohesion }\end{array}$ \\
& $\begin{array}{l}\text { Logic } \\
\text { Details (spelling, punctuation, grammar, abbreviation) }\end{array}$ & 40 \\
\hline
\end{tabular}

\section{Results}

Table 4 provides the results of the tests based on a comparison between the pretest and posttest in terms of faithfulness (total grade: 40), smoothness (total grade: 40) and other aspects (total grade: 20). The numbers shown below were the average grade for each component.

Table 4. Results of Pretest and Posttest

\begin{tabular}{lll}
\hline Standards & Pretest & Posttest \\
\hline Faithfulness & 26.74 & 29.93 \\
Smoothness & 24.92 & 27.24 \\
Other & 10.85 & 12.36 \\
Total grade & 62.51 & 69.53
\end{tabular}

From the above table, the average score for faithfulness increased by 2.99 ; smoothness increased by 2.32 ; others increased by 1.51; and the average total score increased by 7.02, which has seldom been observed in business English translation courses using a traditional lecture-centred methodology. Therefore, this paper concluded that the flipped learning approach can positively affect Chinese independent college students' business English translation competence.

\section{Discussion}

This study demonstrated that a flipped learning approach can play a positive role in a business English translation course taught at a Chinese independent college by enhancing students' participation in the classroom and improving their translation skills.

\subsection{Discussion of the Current Situation of Business English Translation Courses in China}

Currently, business English translation courses have several issues that need to be urgently addressed:

1) The teaching content lags behind or is not compatible with the demand of the market, which makes graduates unable to meet the requirements of the job market.

2) The traditional lecture-centred methodology is not effective. The traditional method of teaching business English translation is, to some extent, effective in enhancing students' knowledge of basic translation skills for certain kinds of business texts. However, the lecture-centred approach also limits students' class participation and reduces their passion about translation while leading them to passive knowledge acquisition. This method also leads to little improvement in students' translation skills and is inefficient.

3) Instructors do not take advantage of modern, advanced technology and online resources.

The problems listed above suggest the need for reforms in courses for business English translation taught at Chinese universities, especially in Chinese independent colleges because of the characteristics of their students.

\subsection{The Efficacy in One Chinese Independent College}

Because the students in this independent college have relatively weak English proficiency and usually lack initiave in study because they have always been spoon-fed the knowledge, they have limited interest in translation and can be discouraged by a traditional teacher-centred, exam-based teaching methodology. The teacher in a flipped-learning class, however, plays only the role of providing learning materials (e.g. videos), assistance and guidance; and observing the translation process. Moreover, students are put in the centre of the 
class and provided ample time to learn in advance and translate texts in class. Once provided with the necessary knowledge before class, students can actively participate in raising issues, solving problems and translating texts after group discussion. Results in this study have demonstrated the flipped learning model can be an effective way to teach a business English translation at this Chinese independent college.

\section{Conclusion}

The limitation of this study should be noted: this 16-week application of a flipped learning approach for a business English translation course taught at the Yangtze University College of Arts and Science had a limited number of participants (26 students). However, because there are no research publications about using the flipped learning approach for a business English translation course taught at a Chinese independent college, this study draws conclusions that have far-reaching potential for the research field of flipped learning approach in business English translation courses. Nevertheless, the author feels that the limitations of this study are inevitable owing to the very limited number of participants in just one Chinese independent college. More empirical studies are required to further prove the efficacy of the flipped learning approach in business English translation courses in Chinese independent colleges.

\section{Acknowledgments}

I would like to express my gratitude to all those who helped me during the writing of this paper. I am also greatly indebted to the students participating in this study who are highly cooperative and helpful. Last my thanks would go to my beloved family for their loving considerations and great confidence in me.

\section{References}

Bergmann, J., \& Sams, A. (2012). Flip your classroom: Reach every student in every class every day. Eugene, Or: International Society for Technology in Education.

Deng Lijun. (2018). The Project-Based Flipped Learning Model in Business English Translation Course: Learning, Teaching and Assessment. English Language Teaching, 11(9), 118-128. https://doi.org/10.5539/elt.v11n9p118

Educause Learning Initiative. (2012). 7 Things You Should Know About Flipped Classrooms. Retrieved from https://ibrary.educause.edu/ /media/files/library/2012/2/eli7081-pdf.pdf

Flipped Learning Network. (2015). What is Flipped Learning. Retrieved from https://flippedlearning.org/wp-content/uploads/2016/07/FLIP_handout_FNL_Web.pdf

He Jing, \& Li Shuangling. (2020). Effectiveness of a Flipped Classroom and Factors Contributing to Its Effectiveness: An Experiment and Questionnaire Survey in Business English Translation Course. Business English Teaching and Research.

Hui Fan. (2018). Strategies of Business English Translation from the Perspective of Functional Equivalence. Advances in Literary Study, 6(1), 19-29. https://doi.org/10.4236/als.2018.61003.

Jenkins, M., Bokosmaty, R., Brown, M., Browne, C., Gao, Q., Hanson, J., \& Kupatadze, K. (2017). Enhancing the Design and Analysis of Flipped Learning Strategies. Teaching \& Learning Inquiry, 5(1), 65-77. https://doi.org/10.20343/teachlearninqu.5.1.7

Ji Jiaoyang. (2021). An Exploration into the Teaching Plan of Flipped Learning in a Russian Translation Course. Foreign Language Teaching and Research, (7), 46-47.

Li Guohui. (2021). The Teaching Design for a Business English Translation Flipped Classroom in the Era of Mass Data. Foreign Language Teaching and Research, (1), 54-55.

Wang Jing, \& Huang Quancan. (2016). The Empirical Research on the Teaching Model of a "Flipped Classroom" in College Business English Translation Course. Journal of Chaohu College, 18(1), 151-155.

$\mathrm{Xu}$ Yuecheng. (2016). The Empirical Study of Applying a Flipped Classroom to Business Interpretation in a Chinese Polytechnic College. Economic and Trading Practice, (12), 232-248.

\section{Copyrights}

Copyright for this article is retained by the author(s), with first publication rights granted to the journal.

This is an open-access article distributed under the terms and conditions of the Creative Commons Attribution license (http://creativecommons.org/licenses/by/4.0/). 